\title{
IDEOLOGIA JUDAICO-CRISTA: A VIOLÊNCIA SIMBÓLICA CONTRA A MULHER TRANSMITIDA HISTORICAMENTE E REPRODUZIDA PELOS AGENTES ESCOLARES
}

\author{
Andreza Marques de Castro LEÃO ${ }^{1}$ \\ Francisco de Paiva Lima NETO ${ }^{2}$ \\ Dulce Consuelo Andreatta WHITAKER ${ }^{3}$
}

RESUMO: A ideologia oriunda do pensamento religioso transita na sociedade por meio dos seus agentes formadores. No contexto escolar nota-se uma realidade aplicável ao conceito de violência que estabelece uma cultura de submissão da mulher ao homem e que se reproduz por meio destes agentes. De fato a ideologia religiosa da cultura judaico-cristã chegou à educação nas suas várias nuances, inclusive na cultura escolar de maneira sutil, através da interiorização de seus conceitos pelos indivíduos que o assimilaram como natural. Considerando esta realidade, o presente estudo, de cunho teórico, problematiza o conceito de ideologia, buscando compreender a trajetória da sujeição da mulher, da antiguidade aos dias atuais, bem como, esboça o quadro político da contra-ideologia. Em linhas gerais, busca mostrar que os adeptos da cultura judaicocristã persistem em perpetuar a violência simbólica contra a mulher a qual tem sido cada vez mais questionada, principalmente, quando confrontada com os escritos do criador do cristianismo, que colocou a mulher em condição e tratamento de igualdade, sem desvalorização. Outrossim, este artigo denuncia que é preciso um olhar mais atento da academia às sutilezas dos livros considerados sagrados, pois podem trazer importantes elementos para a compreensão dos muitos mitos e tabus das relações de gênero presentes na contemporaneidade.

PALAVRAS-CHAVE: Violência simbólica. Mulher. Ideologia. Escola. Relações de gênero.

\section{INTRODUÇÃO}

Abordar a condição de gênero, e neste contexto, falar sobre a mulher é muito complexo, visto suas implicações interdisciplinares e os seus desdobramentos ideológicos que perpassam pela antropologia, sociologia, psicanálise, medicina, religião, entre outros campos de estudos.

\footnotetext{
${ }^{1}$ UNESP - Universidade Estadual Paulista. Faculdade de Ciências e Letras - Departamento de Psicologia da Educação. Araraquara - SP - Brasil. 14800-901. Doutora em Educação Escolar com Pós-Doutorado em Sexologia e Educação Sexual. UNESP - Universidade Estadual Paulista. Faculdade de Ciências e Letras - Programa de Pós-Graduação em Educação Sexual. Araraquara - SP - Brasil. 14800-901 andrezaleao@fclar.unesp.br

${ }^{2}$ Professor Doutor de História da Rede Pública Estadual e Municipal de Araraquara - SP. Gerente de Políticas Educacionais da Secretaria Municipal de Educação de Araraquara. chiquinho.paiva@ gmail.com

${ }^{3}$ Co-editora da revista Retratos de Assentamentos, do Núcleo de Pesquisa e Documentação Rural (NUPEDOR). UNESP - Universidade Estadual Paulista. Faculdade de Ciências e Letras - Programa de Pós-Graduação em Educação Sexual. Araraquara - SP - Brasil. 14800-901. - sil.onofre@ uol.com.br
} 
De fato, a questão de gênero suscita discussões, as quais precisam ser veementemente instigadas, visando minar preconceitos e estigmas que foram tecidos historicamente a respeito da mulher. Aliás, a sexualidade é um assunto envolto de mitos e interditos, e para abarcá-la é pertinente um resgate histórico, porquanto a partir disso é possível desvelar de onde vem as práticas e os tabus sexuais que existem e persistem na contemporaneidade.

Como ponto de partida, vale mencionar que a compreensão histórica da sexualidade é permeada por diferentes momentos. Para que se possa compreender o papel que a mulher representa na sociedade contemporânea é importante considerar que este está relacionado as variação no tempo e no espaço, sendo que um recorte histórico se faz necessário para a abrangência da condição feminina ${ }^{4}$. Para tal é imprescindível ponderar acerca da relevância da civilização judaico-cristã, sobretudo porque a sociedade ocidental é baseada nesta civilização.

Este artigo, de cunho teórico, tem por objetivo realizar um estudo sobre a ideologia oriunda do pensamento religioso que transita em agentes formadores da cultura escolar (educadores e educados), e que justifica a dominação do homem sobre a mulher, isto é, a violência simbólica.

Cabe iniciar lembrando que toda espécie de dominação caracteriza-se como violência (LIMA NETO; LEÃO, 2013). Não podemos entender o conceito de violência somente como agressão física. Segundo BOURDIEU (2001, p.202), as ações pedagógicas "quando tencionam desenvolver a sensibilidade a uma forma particular de capital simbólico" se caracterizam como violência simbólica por se tratar de um poder cultural imposto arbitrariamente.

Portanto, para esses autores, qualquer forma de coação, seja ela econômica, social ou simbólica é uma violência.

No caso específico, a violência simbólica é engendrada historicamente durante o processo de socialização dos indivíduos (LIMA NETO; LEÃO, 2013). É nesse processo (no qual forma-se o que Bourdieu chama de habitus), que os indivíduos, impulsionados por ideologias dominantes, sempre se posicionam no espaço social seguindo os critérios e padrões do discurso dominante. Bourdieu e Passeron (1975), estudando o sistema educacional francês e, considerando a arbitrariedade do sistema

4 Embora não realizamos nenhuma citação das obras de Rosand Milles, torna-se imperativo informar ao leitor a importância da obra "The Women's History of the World" a qual em 1989 foi publicada no Brasil com o título: "A História do Mundo pela Mullher". 
simbólico (cultura) dado como natural em uma determinada sociedade que procura manter-se e perpetuar-se, por meio da ideologia interiorizada pelos indivíduos que a compõem, entendem que estes vitimados pela imposição de uma cultura dominante, não se opõem ao opressor, por considerar sua situação natural e inevitável, ou em suas palavras: "quando são dadas as condições sociais de imposição e inculcação" (BOURDIEU; PASSERON, 1975, p.22).

A construção desta ideologia se dá por diversos meios, como por exemplo, a família, a escola, a religião, a mídia, dentre outros. Louis Althusser (1985) considera que não é suficiente a dominação apenas por instrumentos repressores, sendo necessários aparelhos ideológicos. Esse pensador classifica-os como AIE (aparelho ideológico de Estado), dividindo-os em AIE religioso (os sistemas das diferentes Igrejas), AIE escolar (o sistema das diferentes escolas públicas e particulares), AIE familiar, AIE jurídico, AIE político (os sistemas políticos que fazem parte os diferentes partidos), AIE sindical, AIE da informação (imprensa, rádio, televisão, etc.) AIE cultural (Letras, Belas Artes, Desportos, etc.). Entendemos que, como em Althusser, a análise de Bourdieu tem um caráter reprodutivista, colocando o indivíduo como "prisioneiro" de ideologias, sem a possibilidade de superá-las. Embora classificando as suas análises como reprodutivistas, não desmerecemos suas preciosas contribuições para pensar a cultura escolar. Considerando que ao elaborar seus estudos sobre violência simbólica, Bourdieu fez menção ao sistema escolar francês, e para efeitos do arcabouço teórico, emprestamos seus conceitos: no entanto entende-se que transpô-los totalmente como ferramenta de compreensão da realidade escolar brasileira no século XXI seria uma simplificação.

Neste artigo apenas identifica-se uma realidade aplicável ao conceito de violência simbólica imposta historicamente por uma ideologia religiosa, porém, há possibilidade de superação das ideologias, não as entendendo como indeléveis características reprodutivistas das classes dominantes. Assim, há a possibilidade de transformações e mudanças.

Ademais, compreende-se que o processo educativo não é restrito à educação escolar, assim como as ideologias não surgem mecanicamente a partir de préelaborações de aparelhos ideológicos de Estado, mas brotam historicamente das relações sociais. Desta feita, entende-se que a violência simbólica que impõe uma cultura de submissão da mulher ao homem não se constrói e nem se reproduz tão 
somente nos sistemas escolares. Porém, os agentes escolares são seus portadores. Podem, no entanto, usá-la como instrumento de reprodução ou de ruptura.

Este discurso, objeto do presente artigo, fora construído historicamente por meio de uma ideologia religiosa da cultura judaico-cristã, elaborado em forma de teologia, e chegou à educação nas suas várias nuances, inclusive na cultura escolar de maneira sutil, através da interiorização de seus conceitos pelos indivíduos que o assimilaram como natural. Para melhor organizar estas ideias o presente trabalho será subdividido nos seguintes tópicos: 1) O Quadro teórico - conceito(s) de Ideologia; 2) O Quadro histórico - a trajetória da sujeição da mulher da antiguidade aos dias de hoje; 3) O quadro político - a proposta de uma contra-ideologia e; 4) Considerações finais.

\section{O QUADRO TEÓRICO - CONCEITO(S) DE IDEOLOGIA}

O conceito de ideologia é amplo e sua literatura é rica. Sobre esse tema trabalham não só filósofos e sociólogos, como também psicólogos, historiadores, cientistas políticos, dentre outros (LIMA NETO; LEÃO, 2013). Marx e Engels (1979), na obra "Ideologia Alemã", explicam a formação da consciência humana, segundo uma concepção materialista. Nela, esses autores entendem que a consciência humana é resultado das condições materiais de sua produção:

O espírito tem consigo de antemão a maldição de estar preso a
matéria, a qual nos surge aqui na forma de camadas de ar em
movimento, de sons, numa palavra da linguagem,. A linguagem é tão
velha como a consciência [...] e a linguagem só nasce, como
consciência, da necessidade, da carência física do intercambio com
outros homens. A consciência é pois, logo desde o começo, um
produto social, e continuará sê-lo enquanto existirem homens.
(MARX; ENGELS, 1979, p.34).

Marilena Chauí (1980, p.3) define ideologia como: “[...] um conjunto lógico, sistemático e coerente de representações (ideias e valores) e de normas ou regras (de conduta) que indicam e prescrevem aos membros da sociedade o que deve pensar e como devem pensar, o que devem fazer e como devem fazer". Para ela, portanto, a ideologia é um conjunto de representações condensadas em um corpo explicativo e prático com normas, regras, e preceitos de caráter prescritivo e regulador que tem a função de dar aos membros de uma sociedade dividida em classes uma explicação racional para as diferenças sociais, políticas e culturais, sem atribuir tais diferenças à 
divisão da sociedade em classe, a partir das divisões na esfera da produção (LIMA NETO; LEÃO, 2013).

Segundo esse entendimento é justamente a ideologia que obstaculiza a percepção da alienação e impede a revolta da classe dominada contra a dominação. Sem precisar recorrer à violência física, a ideologia mantém o consenso e a coesão da sociedade, escondendo as distorções (ou seja, produzindo uma falsa consciência), mascarando as desigualdades sociais e ocultando a exploração do homem pelo homem (LIMA NETO; LEÃO, 2013). Nessa concepção, ideologia é entendida simplesmente como uma "máscara da realidade". Na prática, a ideologia é absorvida também pela classe dominada e esta torna-se refém dos discursos que fazem a percepção da realidade pelos dominantes, ou seja - há um discurso hegemônico que obstrui aos dominados terem a sua própria visão de mundo.

Outro pensador marxista, Antônio Gramsci (1995) estabelece algumas diferenças na compreensão deste conceito. Não é fácil trabalhar com o conceito de Ideologia de Gramsci. Lima Neto e Leão (2013) explicam que isso não ocorre somente por sua profundidade e complexidade, mas também pelo fato das circunstâncias de sua vida não terem permitido que ele deixasse uma obra teórica sistematizada.

Especificamente na área religiosa, Gramsci (1995) classifica a religião como ideologia que não pode ser provada objetivamente como realidade observável. Para ele a religião não pode fazer parte do mundo científico, limitando-se ao campo filosófico, pois ela é classificada como concepção de mundo.

Além disso, ele refere que a realidade objetiva é "[...] aquela realidade que é verificada por todos os homens, que é independente de todo ponto de vista que seja puramente particular ou de grupo" (GRAMSCI, 1995, p.65). Sobre a religião, que não é verificada de maneira única por todos os homens, mas "é uma concepção particular do mundo", afirma ser ideologia.

A verdade científica, observável por todos os homens, para Gramsci deve se afastar do senso comum, que segundo ele, comete erros grosseiros, pois não estabelece os nexos reais de causa e efeito. Este pensador questiona a verdade científica que se renova historicamente a cada nova experiência. Em suas palavras:

Mas se nem mesmo as verdades científicas são definitivas e peremptórias, também a ciência é uma categoria histórica, um movimento em contínua formação. Se for assim, portanto, o que interessa à ciência não é tanto a objetividade do real quanto o homem 
que elabora os seus métodos materiais que reforçam os órgãos sensoriais e os instrumentos lógicos. (GRAMSCI, 1995, p.69).

Ao entender a ciência como uma categoria histórica, classifica-a também como ideologia, pois entende que a cultura que expressa uma concepção do mundo, nada mais é do que a relação entre o homem e a realidade mediada pela tecnologia (LIMA NETO; LEÃO, 2013). Nesta relação o homem é o criador de valores, inclusive científicos, sem o qual o universo não teria significado por si só, mas significa aquilo que o homem interpreta. Decorrente disso, o ser não pode ser separado do pensar nem o sujeito do objeto, conforme a concepção da filosofia da práxis. Gramsci (1995, p.70) salienta que:

Colocar a ciência na base da vida, fazer da ciência a concepção do mundo por excelência, a que liberta os olhos de qualquer ilusão ideológica. Mas na realidade, também a ciência é uma superestrutura, uma ideologia. Sua reação sobre a estrutura tem um caráter particular, de maior extensão e continuidade de desenvolvimento, notadamente após o século XVIII.

Também exemplifica que é possível a um grupo social se apropriar da ciência de outro, sem aceitar sua ideologia, ao mencionar o fato histórico dos cristãos apropriaremse da ciência e das técnicas árabes, que eram consideradas por eles como bruxarias, sem contudo, apropriar-se de seus princípios religiosos. Neste exemplo demonstra que uma ideologia dominante (no caso a religião cristã) ocultou por um grande período a origem dos conhecimentos árabes.

Joll (1977) ao discorrer sobre Gramsci enfatiza a importância que este deu à superestrutura, colocando o problema da ideologia e cultura não como decorrente da infra-estrutura econômica apenas, mas como possibilidade de conquista através de choques de hegemonias. Esse novo olhar, segundo ele, foi em função da continuidade do marxismo após a sobrevivência do capitalismo.

Esse mesmo autor observa que Gramsci rejeitou o materialismo dialético grosseiro na tentativa de reformular a doutrina do materialismo histórico, enfatizando a importância da influencia das ideias na História, bem como, no impacto da vontade individual nas influências intelectuais. Segundo ele, Gramsci ao desenvolver seu conceito de "hegemonia" (doutrina gramsciana que explica como determinado sistema social e econômico se sustenta e mantém sua base de apoio), entende que o domínio de uma classe sobre outra não é decorrente apenas do poder econômico, ou da força física, 
mas também da persuasão que classe dominada sofre dos valores sociais, culturais e morais da dominante (JOLL, 1977).

Badaloni (1978, p.11) entende que o conceito de "choque de hegemonias" difere de "choque de ideologias", mas esse choque ideológico, segundo ele, reflete sensivelmente o choque das relações sociais existentes e possibilidades de surgimento de novas. Em suas palavras,

As ideologias não são nesse caso meros reflexos de uma realidade que está por trás delas, mas, ao contrário , são manifestações do choque das realidades correspondentes a dois modos de produção visíveis historicamente. Trata-se de ideologias que sintetizam um modo diverso de comportar-se na presença de estruturas sociais diversas. $\mathrm{O}$ choque ideológico reflete sensivelmente choque das relações sociais existentes como outras e novas que emergiam e impuseram uma moral conforme a elas.

Ao considerar a importância da ideologia e cultura (superestrutura), não considera Gramsci um opositor ao marxismo, mas um continuador de Marx que supera a derivação da cultura com predominância (LIMA NETO; LEÃO, 2013). Observa-se em seus comentários que enfatiza a importância superestrutral da sociedade: seus argumentos consistem na diferenciação que ele faz entre Marx e Gramsci. Essa diferenciação consiste no fato de que o sistema de crenças se insere, para Marx, num modo de produção determinado, e para Gramsci na atualização de novas crenças.

Em suas palavras observa que:

[...] em Marx, ocorre a seguinte progressão: 1. O modo de produção produz uma pratica social conforme; 2 . as crenças tornam-se funções de estabilidade da prática social que se institucionaliza; 3. Elas tornam possível a ciência dessa prática; 4 . A crítica da ciência abre o caminho para novas práticas sociais. Em Gramsci as novas crenças se consolidarão com a sua penetração nos interstícios da velha formação social em crise e a partir disso inicia-se uma luta hegemônica não só entre crenças, mas entre as práticas sociais. (BADALONI, 1978, p.17).

A partir dessa compreensão o autor intereta que Gramsci entende ideologias como práticas de vida determinadas por uma concepção do mundo, ou religiões, não nascendo casualmente, mas a partir de necessidade estruturais profundas e que são capazes de influir duradouramente sobre a prática. 
Nesta mesma linha de pensamento, Badaloni diz que a pesquisa de Gramsci não desconsidera o papel do econômico como determinante em última instância, mas sim estabelece um "novo modo de considerar o muro entre estruturas e superestrutura".

O programa de pesquisa de Gramsci não consiste, assim, em uma remoção do papel do econômico como determinante em última instância, mas sim em um novo modo de considerar o muro entre estruturas e superestrutura. O "ideológico" pode, em determinadas condições, não ser um simples reflexo estático das estruturas, mas assumir o papel de catalisador, tanto nas crenças populares quanto na ciência e na sua crítica, da passagem de uma formação social a uma outra. "Emanação 'orgânica' de necessidades econômicas", determinação orgânica e uma determinação de tipo mecânico. (BADALONI, 1978, p.25).

Conforme apontam Lima Neto e Leão (2013), a leitura de Joll e Badaloni aponta não somente a complexidade do pensamento de Gramsci, mas também pequenas nuances na leitura que cada um faz de seus escritos, inclusive abordando o conceito de ideologia. Em uma análise primária pode-se constatar que a preocupação de Joll é ênfase que Gramsci dá ao aspecto cultural procurando deslocar o materialismo do marxismo ortodoxo. Badaloni procura amenizar esse conflito, observando que muito embora as teorias gramscianas valorizem a superestrutura, não desconsideram a base econômica.

Além da leitura de Gramsci segundo os autores acima mencionadas, tem-se a visão particular sobre as ideias deste pensador. Em sua obra Os intelectuais e a produção da cultura (GRAMSCI, 1978) ele faz considerações importantes para se compreender a função da intelectualidade e da escola. Seus textos mostram uma visão diferenciada de Marx no que se refere à formulação de ideologias. Se para Marx a ideologia brota dos interesses da classe dominante, sendo imposta a todas as classes como falsa consciência, para Gramsci não há um discurso hegemônico em toda a sociedade, mas há visões de mundo para os diferentes grupos ou classes. Essas visões diferenciadas de cada grupo ou classe produzem intelectuais para si:

Cada grupo social, nascendo no terreno originário de uma função essencial no mundo da produção econômica, cria para si, ao mesmo tempo, de um modo orgânico, uma ou mais camadas de intelectuais que lhe dão homogeneidade e consciência da própria função, não apenas no campo econômico, mas também no social e no político [...] (GRAMSCI, 1995, p.3). 
Para ele "todos os homens são intelectuais" e a intelectualidade tem uma função social. Não diferencia como Marx a intelectualidade clássica (humanista) da técnica (profissional), pois, para ele, não há distinção entre o homo faber e o homo sapiens, pois como já foi dito todos os homens são intelectuais. Dando continuidade ao raciocínio de Gramsci, para ele as formulações ideológicas seriam uma construção mental realizada por cada grupo ou classe, e não somente pela classe dominante. Na obra citada, ele divide os intelectuais em dois grupos: 1) os chamados tradicionais, os quais seriam independentes, e 2) orgânicos, ou seja, o conjunto de intelectuais que estão ligados a cada grupo social, e produzem o pensamento para sua categoria.

Entende-se que os conteúdos discursos não nascem no vácuo, portanto não são individuais, neutros nem autônomos, mas estão inseridos dentro de uma categoria que fora construída em um processo histórico (LIMA NETO; LEÃO, 2013). Conforme os referidos autores salientam "Há, na realidade, diversidade de visões de mundo que estão postas pelo trabalho de intelectuais que são representantes de diversas categorias e disputam hegemonia na arena filosófica.” (LIMA NETO; LEÃO, 2013, p.159).

\section{O QUADRO HISTÓRICO - A TRAJETÓRIA DA SUJEIÇÃO DA MULHER DA ANTIGUIDADE AOS DIAS DE HOJE}

As mulheres desde a Antiguidade e até o término do século XIX apresentavam papel secundário na sociedade. No contexto histórico cultural em diferentes civilizações elas geralmente foram vistas como inferiores aos homens. As desvantagens que elas apresentavam era em relação a leis, religião, normas e padrões de conduta, porquanto estes sempre tiveram caráter exclusivamente masculino.

Cabe pontuar que na conjuntura bíblica predominava o patriarcalismo, no qual os homens eram produtivos, exerciam funções administrativas e militares, eram detentores do saber, e chefiavam os lares. Já as mulheres desempenhavam as funções domésticas, de cuidar do lar e dos filhos, não podendo participar ativamente da religião e das decisões políticas, a não ser sob obediência absoluta ao homem.

A consolidação do patriarcado produziu uma relação entre os sexos, na qual a complementaridade converteu-se numa radical assimetria e, em certos modos, em exclusão das mulheres. Logo, a ideologia patriarcal não só legitimou o poder masculino, mas também converteu os homens no bem, atribuindo o mal às mulheres, assim, justificando a imposição da sua submissão (PETERSEN, 1999). 
O fenômeno do patriarcado tem origens e se reporta no fato também universal da responsabilidade exclusiva das mulheres pelos cuidados dos filhos. A herança cultural revela a subordinação da mulher, cujo contexto de vida era resumido à esfera domiciliar.

Francisca Silva (2008) menciona que as mulheres no judaísmo primitivo eram excluídas da vida pública, e aprendiam quando crianças os serviços domésticos, costura, fiação e cuidar dos irmãos menores. Elas não tinham o mesmo direito que os irmãos homens, sendo que a família judaica é de tradição patriarcal, tudo é centrado na figura paterna.

Trazendo esta discussão ao contexto bíblico, no livro de Gênesis 2:18, encontra-se um dos textos que relatam a condição da mulher como auxiliadora do homem, como aprova tal afirmação: "Não é bom que o homem esteja só. Far-lhe-ei uma auxiliadora que lhe seja idônea".

Este trecho evidencia que a mulher na conjuntura judaica tinha um papel, sendo este de auxiliar do homem. Pode-se dizer que sua função era estar junto deste, de atendê-lo quando necessário. Nota-se que prestar auxílio não significa subordinação da mulher, tampouco abre a prerrogativa para ser tratada de forma desigual e inferior. Entretanto, nesta conjuntura história a mulher não era sequer vista como um ser de direitos, e auxiliar o homem era uma exigência social, algo que ela tinha obrigação de fazer.

O sistema patriarcal determinava como as mulheres deviam ser tratadas. Deste modo, elas eram discriminadas e semi-escravizadas pelo marido, pai ou senhor. Silva (2008), ao discorrer sobre a figura paterna, explica que a menina no judaísmo tinha a obrigação de cuidar do pai, e isso significava alimentá-lo, vesti-lo, cobri-lo, dar de beber, ajudar a entrar e a sair de casa, entre outros. A citada pesquisadora complementa dizendo que as filhas dependiam totalmente dos pais até se casarem: isso ocorria por volta dos 12 anos, e a autoridade do pai era transferida para o marido, sendo que ela deveria também cuidar do esposo.

O papel da mulher era obedecer, primeiramente ao pai, depois ao marido, como vemos em Gênesis 3:16: “Teu desejo será para o teu marido, e ele te governará”. Em outras palavras, a mulher devia obediência ao marido como seu senhor (SILVA, 2008).

Além disso, as mulheres eram vistas como propriedade do homem e colocadas no mesmo patamar dos bens que ele possuía. Em uma das passagens bíblicas do Velho 
Testamento, Êxodo 20:17, fica bem clara isso: "Não cobiçarás a casa do teu próximo, não desejarás a sua mulher, nem seu servo, nem a sua serva, nem o seu boi, nem o seu jumento, nem coisa alguma que pertença ao seu próximo."

A mulher era educada para assumir este papel social, haja vista que havia uma diferenciação na educação das mulheres e dos homens desde a infância. Ela era criada para casar, cuidar do lar e dos filhos, fiar, tecer e moer, enquanto os homens para tomar decisões, para governar sua futura família.

De acordo com Nunes (1987, p. 68) “a submissão, a contenção e a obediência são as virtudes da mulher ideal, como vemos em muitos textos bíblicos". Cabe esclarecer que esta submissão era total e irrestrita ao homem, ao marido, porquanto as mulheres eram criadas para constituírem famílias, e deveriam, portanto obedecer aos seus esposos, lembrando que esta subordinação e sujeição eram vistas como qualidade da mulher, característica imprescindível de uma boa esposa.

A igreja cristã auxiliou no surgimento de padrões tradicionais de masculino e feminino, de tal forma, que parecem originados naturalmente, padrões estes que interferem bruscamente a relação de gêneros, favorecendo a manutenção de uma ordem social e ideológica patriarcal e machista, as quais foram e tem sido largamente divulgadas e assimiladas acriticamente.

\section{O QUADRO POLÍTICO - A PROPOSTA DE UMA CONTRA IDEOLOGIA}

Nota-se a construção histórica de uma ideologia que subjugou a mulher, vitimando-a através de uma violência simbólica, por ela aceita como natural. Porém, encontra-se ainda em escritos aceitos pelo cristianismo um discurso diferenciado que pode servir de contra ideologia libertadora. Se categorias dominantes historicamente impuseram uma ideologia com pretensões hegemônicas, há discursos a serem enfatizados que tornaram-se ideologias subversivas e que produzem um choque de ideologias. Emprestando o conceito de Gramsci, intelectuais independentes podem constatar em textos da Bíblia que relatam os ensinamentos apregoados por Jesus Cristo, figura central do cristianismo, que podem ajudar a construir uma contra ideologia para romper os estigmas da mulher perante a sociedade, numa época em que o patriarcalismo judeu era incontestável. 
Diante de tal fato, este tópico, de cunho bibliográfico, analisará a mulher na cultura judaica, demonstrando como Jesus as tratou, e o papel que ele exerceu neste contexto histórico, à luz da Bíblia, livro sagrado dos cristãos. Além de lançar mão deste livro, dialogará com autores que analisam a condição da mulher no contexto do judaísmo primitivo.

Geralmente pesquisas que se propõem a analisar uma religião são restritas na academia. Aliás, como Maria Araújo (2012, p.290, grifo nosso) alerta,

[...] no modismo da atualidade prevalecem discursos contrários, incisivos e machistas, elaborados por acadêmicos que defendem a supremacia do homem sobre várias mulheres submissas, como um fator de diversidade cultural que deve ser mantido e respeitado. Eles sequer cogitam a possibilidade de opressão feminina nesse contexto sexual que, do ponto de vista cristão, é violento, convencional e desrespeitoso por coisificar e rebaixar as mulheres à categoria de objetos utilitários.

Sendo assim, pensando na cultura ocidental e no papel da mulher, que sofreu e sofre as influencias do judaísmo, é importante desvelar as percepções e atitudes de Jesus, considerado pelos cristãos a personagem principal da Bíblia.

A luta das mulheres por igualdade de direitos está registrada na história da humanidade, através de mitos, contos, crenças e principalmente através de documentos. De fato, esta história é marcada por exclusões, violências e inferiorizações das mulheres. Na cultura judaica, por exemplo, as mulheres não eram escutadas, nem detentoras de direitos. A justificativa para tal atitude era que elas precisavam ser protegidas e amparadas.

O adultério era considerado ofensa para o homem, sendo que o divórcio era prerrogativa unicamente para os homens.

Se um homem tomar uma mulher e se casar com ela, e se ela não for agradável aos seus olhos, por ter ele achado coisa indecente nela, e se ele lhe lavrar um termo de divórcio, e lho der na mão, e a despedir de casa; e se ela, saindo da sua casa, for e se casar com outro homem; e se este a aborrecer, e lhe lavrar termo de divórcio, e lho der na mão, e a despedir da sua casa ou se este último homem, que a tomou para si por mulher, vier a morrer, então, seu primeiro marido, que a despediu, não poderá tornar a desposá-la para que seja sua mulher, depois que foi contaminada, pois é abominação perante o Senhor. (BÍBLIA, Deuteronômio, 24, 1-4). 
Ademais, o apedrejamento à mulher adúltera era um fato corriqueiro entre os povos israelitas especialmente em casos de prostituição, adultério ou perda da virgindade feminina (ARAÚJO, 2012, p.292). De acordo com a lei, se "não tiverem comprovado as marcas da virgindade da jovem [...] os habitantes de sua cidade a apedrejarão até que morra." (BÍBLIA, Deuteronômio, 22, 20-21). Não há menção a virgindade do homem, visto que era uma exigência que recaia sobre a mulher.

Em relação à herança, se a mulher a possuísse (por falta de irmãos) ela tinha de se casar com alguém da mesma tribo a fim de preservar os bens herdados, os quais passavam a ser administrado pelo marido. Como diz o trecho bíblico, "Desse modo cada israelita herdará a terra dos seus antepassados, e ela não passará de uma tribo para outra. Cada tribo continuará ligada à sua própria terra" (BÍBLIA, Números, 36, 9).

Embora fosse comum que as mulheres de posses contribuíssem para o sustento de rabis, eles preferiam evitar sua companhia. Peter Brown (1990) expõe que eles evitavam a humilhação de parecer depender financeiramente de uma mulher.

Foi em meio a estes aspectos da cultura judia que Jesus nasceu. Não obstante, ele revolucionou sua época com suas atitudes, entre estas, com sua postura como homem tratando a mulher em pé de igualdade, chamando-as de "filhas de Abraão", formas de tratamento exclusivo dos homens. Ele aparece e ensina um modo distinto, até então, de tratá-las, demonstrando, com suas ações, que tanto homens quanto mulheres, apresentam o mesmo nível de importância diante de Deus.

Segundo Araújo (2012), o líder judaico Jesus de Nazaré rompeu radicalmente com o sexismo de sua época, propondo harmonia entre os gêneros masculino e feminino. Aliás, em seu ministério ele contava com o auxílio financeiro de mulheres.

O trecho que segue exemplifica isso: "Se alguém vem a mim e não aborrece a seu pai, e mãe, e mulher, e filhos, e irmãos, e irmãs e ainda a sua própria vida, não pode ser meu discípulo" (BÍBLIA, Lucas, 14, 26).

Jesus tinha discípulas, admitindo-as no seu círculo de amizades. Este comportamento diferia dos judeus, além disso, ele permitia que elas trouxessem seus filhos para vê-lo.

Aconteceu, depois disto, que andava Jesus de cidade em cidade e de aldeia em aldeia, pregando e anunciando o evangelho do reino de Deus, e os doze iam com ele, e também algumas mulheres que haviam sido curadas de espíritos malignos e de enfermidades: Maria, chamada Madalena, da qual saíram sete demônios; e Joana, mulher de 
Cuza, procurador de Herodes, Suzana e muitas outras, as quais the prestavam assistência com os seus bens. (BÍBLIA, Lucas, 8, 1-3).

Karen King (1998), em seu instigante estudo intitulado "Mulheres no Cristianismo Antigo: As novas descobertas" refere que os evangelhos do novo testamento, assinala que as mulheres estavam entre os primeiros seguidores de Jesus. Desde o início, os discípulos judeus mulheres, incluindo Maria Madalena, Joana e Susana, haviam acompanhado Jesus durante o seu ministério e o apoiou financeiramente.

Ele falou para as mulheres, tanto em público e privado. Jesus era um visitante freqüente na casa de Marta e Maria, e tinha o hábito de ensinar e comer refeições com as mulheres, assim como com os homens (KING, 1998). Além disso, Jesus investia seu tempo falando e curando mulheres, o que demonstra que ele não tinha vergonha de dar a palavra para elas, fato este diferencial, visto que não os judeus não davam a palavra às mulheres, sobretudo em público.

"Neste ponto, chegaram os seus discípulos e se admiraram de que estivesse falando com uma mulher; todavia, nenhum lhe disse: Que perguntas? Ou: Por que falas com ela" (BÍBLIA, João, 4, 27).

Em relação à passagem da mulher siro-fenícia houve mais que uma conversa: o caso resultou num debate teológico, no qual ela foi encorajada a expor seus pensamentos, suscitando assim, sua capacidade de discernimento. $\mathrm{Na}$ ocasião, os discípulos quiseram expulsá-las da presença de seu mestre, no entanto, Jesus a tratou de modo respeitoso, dando-lhe atenção que os homens da época não propiciavam às mulheres.

\footnotetext{
Esta mulher era grega, de origem siro-fenícia, e rogava-lhe que expelisse de sua filha o demônio. Mas Jesus lhe disse: Deixa primeiro que se fartem os filhos, porque não é bom tomar o pão dos filhos e lançá-lo aos cachorrinhos. Ela, porém, lhe respondeu: Sim, Senhor; mas os cachorrinhos, debaixo da mesa, comem das migalhas das crianças. Então, lhe disse: Por causa desta palavra, podes ir; o demônio já saiu da tua filha. Voltando ela para casa, achou a menina sobre a cama, pois o demônio a deixara. (BÍBLIA, Marcos, 7, 26-30).
}

No Judaísmo as mulheres eram excluídas da atividade central dos rabinos, e não tinham acesso à transmissão da tradição por meio dos estudos intensivos do Torah, livro sagrado dos judeus (BROWN, 1990). Apesar disso, Jesus ensinava às mulheres. É evidente a passagem em que ensinava Maria em sua casa. 
"Tinha ela uma irmã, chamada Maria, e esta quedava-se assentada aos pés do Senhor a ouvir-lhe os ensinamentos" (BÍBLIA, Lucas, 10, 39).

Conforme enfatiza Marilyn Adamson (2006) ele desafiou as leis sociais em relação a ambos os sexos. Naquela conjuntura histórica, existia uma lei que permitia apenas ao marido divorciar-se. Portanto, qualquer atitude da mulher podia resultar num pedido de divórcio, o que devia gerar muita insegurança, visto que o homem que sustentava o lar. Jesus, no entanto, anunciou que ambos, homens e mulheres tinham o direito de se divorciar um do outro, mas somente em caso de adultério. Ele não apoiou o divórcio, nem privilegiou homens ou mulheres, porém, enfatizou que a lealdade e o compromisso eram de responsabilidade de ambos.

Araújo (2012) relata que Jesus teve alento de romper com a lógica poligâmica e patriarcal dos povos judaicos, a exemplo de suas palavras nos evangelhos: "Foi dito aos antigos [...] todo aquele que rejeitar sua mulher, dê-lhe carta de divórcio. Eu, porém vos digo: todo aquele que rejeita sua mulher, a faz tornar-se adúltera." (BÍBLIA, Mateus, 5, 27-32). Para a referida pesquisadora, esta fala de Jesus demonstra a preocupação com a proteção às mulheres desamparadas e oprimidas, no momento em que eram rejeitadas por seus maridos machistas.

Outra lei social dos dias de Jesus era que a mulher que fosse pega em adultério deveria ser apedrejada até a morte. Ao homem, todavia, não era reservado qualquer pena (ADAMSON, 2006). Deste modo, sabendo da maneira como Jesus tratava as mulheres com dignidade, os mestres da Lei e fariseus queriam saber como Jesus lidaria com isso. Então, certo dia, vários homens arrastaram uma mulher, que foi pega em adultério. E desafiaram Jesus a consentir com o apedrejamento dela. Jesus respondeu dizendo que se havia alguém naquela multidão que nunca havia pecado deveria jogar a primeira pedra na mulher, ou seja, a mulher em equidade com o homem, responsável por seus atos (BÍBLIA, João, 8, 3-11).

Quando Jesus foi preso, a mulher manteve-se firme, mesmo quando seus discípulos homens dizem ter fugido, e acompanharam-no ao pé da cruz.

"E também estavam ali algumas mulheres, olhando de longe. Entre elas, Maria Madalena, Maria, mãe de Tiago o menor, e de Jose, e Salomé. Elas o seguiam e serviam enquanto esteve na Galileia. E ainda muitas outras mulheres que subiram com ele para Jerusalém.” (BÍBLIA, Marcos, 15, 40-41).

De fato, é relevante considerar que foram as mulheres que permaneceram aos pés da cruz quando Cristo estava sendo crucificado, enquanto que os discípulos, que 
acompanharam-no em seu ministério, fugiram para preservar suas vidas. Não obstante, terem presenciado a crucificação e sepultamento de Jesus, ao relatarem as notícias sobre a ressurreição aos discípulos eles não acreditaram, tampouco receberam atenção devida, como Jesus fazia, sendo que o testemunho delas foi ignorado.

"Tais palavras lhes pareciam como um delírio, e não acreditaram nelas" (BÍBLIA, Lucas, 24, 11).

Parece que os ensinamentos que Jesus deixou em relação a gênero, de igualdade da mulher perante o homem, não foram assimilados adequadamente pelos discípulos. Foi a uma mulher que Jesus apareceu após ressuscitar. Os discípulos não compreenderam que justamente aquelas que eram consideradas inferiores na sociedade judaica foram as que trouxeram as melhores novas num momento de dor e tristeza. Elas, apesar das circunstâncias contrárias, não abandonaram seu mestre, sendo que ainda tiveram determinação e lealdade para visitar o túmulo, sendo que este estava sendo vigiado pelo império romano.

Após a morte de Jesus, as mulheres continuaram a desempenhar funções de relevo no movimento inicial. Alguns estudiosos chegaram a sugerir que a maioria dos cristãos do primeiro século pode ter sido as mulheres (KING, 1998). O autor prossegue exposto que as cartas de Paulo - datadas de meados do século I dC - e suas saudações a conhecidos oferecem informações sobre muitas mulheres judeus e gentios que eram proeminentes no movimento, tais como: Priscila, Junia, Julia, a irmã de Nereu, que trabalhou e viajou como missionários em pares com os seus maridos ou irmãos (BÍBLIA, Romanos, 16, 3, 7, 15).

King (1998) expõe que Paulo comenta que Priscila e seu marido arriscaram suas vidas para salvar a sua; elogia Junia como um apóstolo de destaque, que tinha sido preso por seu trabalho; Maria e Persis são elogiados por seu trabalho duro (BÍBLIA, Romanos, 16, 6, 12); Evódia e Síntique são chamados de seus companheiros de trabalho no evangelho (BÍBLIA, Filipenses, 4, 2-3). Portanto, tem-se a evidência de que as mulheres eram ativas na divulgação do ministério de Jesus.

Vale observar que o apóstolo Paulo, devido a sua história de vida marcada por uma formação cultural diversificada, tendo cultura grega e sendo também um fariseu convertido ao cristianismo, promoveu um retrocesso no sentido de recolocar para o cristianismo práticas do patriarcalismo. De fato, ele buscou adequar sua fala a ideologia da época, na qual as mulheres eram relegadas a segundo plano. 
Na realidade a postura de Paulo acerca das mulheres fica evidente nas suas recomendações ao escrever para várias comunidades, como por exemplo, em seus escritos de Colossences 3: 18: "Vós, mulheres, estai sujeitas a vossos próprios maridos, como convém no Senhor", Efésios 5: 22: "Vós, mulheres, sujeitai-vos a vossos maridos, como ao Senhor", 1 Coríntios 14: 34: “As vossas mulheres estejam caladas nas igrejas; porque não lhes é permitido falar; mas estejam sujeitas, como também ordena a lei”. É possível que, neste contexto, pelo fato de as mulhres não terem acesso às letras, sendo que por vezes interrompiam a liturgia dos cultos devido as suas dúvidas, por isso Paulo pontua que elas deviam ficar quietas nas igrejas.

Essas considerações não desmeressem a importância e obra deste apóstolo, que como qualquer homem formado pelas confluências ideológicas de sua época, soube sabiamente reconhecer a igualdade entre os cristãos ao escrever aos Gálatas: "Nisto não há judeu nem grego; não há servo nem livre; não há macho nem fêmea; porque todos vós sois um em Cristo Jesus.” (BÍBLIA, Gálatas, 3, 28). Assim, ele coloca homens e mulheres no mesmo patamar de importância.

As mulheres apresentavam pouca influência na cultura daquela época, e nenhuma autoridade religiosa lhes dava o devido valor. Jesus deu a elas o papel de falar aos outros sobre sua ressurreição, revelando aos homens de sua época, com sua sensibilidade, que elas são detentoras de direitos.

No entanto, as suas ações não foram perpetuadas pelos seus seguidores, pois não houve uma alteração quanto ao tratamento dado às mulheres, ao contrário, o sexo feminino sofre expropriação em nome da igreja tradicional cristã, que surgiu aproximadamente um século após a sua morte, a qual associou a sexualidade ao pecado e à mulher, criando a moral sexual pormenorizada e obtusa, através do qual implementaram práticas comportamentais desastrosas, sobretudo para as mulheres, com a repressão sexual (BROWN, 1990).

De acordo com Ovídio Abreu Filho (1981, p. 82), a concepção cristã Bíblica em relação a mulher foi incorporada pela cultura ocidental, na qual muitos dos seus adeptos consideram a mulher como "[...] inferior ao homem e associada às tentações da carne: sem a proteção e o controle masculinos, a mulher se rende à sua sexualidade e se expõe às tentações do demônio."

Os extremistas cristãos sempre condenaram o prazer físico, procurando limitar ao máximo a sexualidade, e esta moral foi destinada sobretudo às mulheres principalmente, como se ela fosse a responsável por instigar a libido, o desejo sexual. 
Araújo (2012) problematiza que a violência machista da lei judaica ainda repercute nos ritos, cultos e até mesmo nas entrelinhas dos discursos acadêmicos de nossa sociedade contemporânea. A mulher ainda é educada para interiorização de seu papel de inferior, de submissa à vontade do homem.

José Macedo (1990) ressalta que no século I d.C. as mulheres estavam sempre acompanhadas de seus maridos em todas as atividades, sendo que nos séculos III e $\mathrm{V}$ a condição da mulher entre os germanos era diferente, pois houve uma profunda regressão da sua pouca importância na sociedade. Outrossim, entre os séculos X e XII a mulher continuou limitada ao âmbito familiar. A educação daquela época ocorria de acordo com os grandes acontecimentos, com influência marcante de Santo Agostinho, filósofo, teólogo, considerado um dos maiores nomes do pensamento cristão que considerava a sujeição feminina na ordem natural das coisas, cabendo a mulher ser governada pelo homem, tal qual o corpo deve ser governado pela alma. Já o homem deveria ser governado apenas pela sabedoria divina.

Nos dias hodiernos se verifica a influência dos ensinamentos de Santo Agostinho, preceitos estes que contribuíram para que as mulheres fossem massacradas e marginalizadas pelos homens durante séculos. Contudo, como seus ensinamentos foram acatados como verdades absolutas, sem espaço para questionamentos, as mulheres, vítimas de tais preceitos, no século XX se despertaram e estão indagando a veracidade deles. Portanto, elas estão mostrando sua força na sociedade, e se apercebendo da sua importância, manifestando-se contrárias ao papel secundário que lhes foram imposto ao passar dos séculos. Em suma, está ocorrendo o se pode chamar de reinserção do feminino na história da humanidade.

Para King (1998), embora os detalhes das histórias dos evangelhos bíblicos possam ser alvos de questionamentos de céticos, em geral refletem o importante papel das mulheres no ministério de Jesus Cristo. Contudo, ao longo da história a liderança institucional da igreja crista tentou apagar as mulheres da história, de fato, extinguir suas marcas.

Enfim, é possível constatar que embora as leis hebraicas aparentem ser retratadas, legitimamente, nos mandamentos de Jesus Cristo, o moralismo patriarcal que rege o judaísmo bíblico tem fundamentos sexistas, expressamente opostos aos preceitos do patriarcalismo cristão (ARAÚJO, 2012). A autora complementa dizendo que as narrativas do Novo Testamento têm uma importância histórica, além da hermenêutica, pois os discursos de Jesus Cristo compõem, coletivamente, uma voz 
humana e solidária, pregando a paz, o amor e o respeito entre as pessoas, não importando a sua nacionalidade, etnia, cultura, classe social ou gênero.

\section{CONSIDERAÇÕES FINAIS}

Quando se pensa o tema violência na atualidade tem que se colocar em pauta todas as suas formas e nuances, inclusive as violências simbólicas. A escola, como instituição, é produtora de violência simbólica, ou de quaisquer outros tipos de violência, mas é parte de um sistema social e ideológico construído historicamente. A violência contra a mulher não ocorre somente de maneira física. Estudos de gênero têm demonstrado que, embora no século XXI, ainda haja discursos e práticas que submetem mulher a uma categorização inferior. A escola não criou e nem reproduz essa cultura, mas abriga indivíduos (educadores e educandos) que são portadores dessa cultura.

Desse modo, a prática da reprodução cultural dessa ideologia faz com que a mulher continue sendo vítima de um processo histórico cultural de predomínio do sistema patriarcal. Este sistema, porém, não foi hegemônico. Desde a antiguidade houve uma contra-ideologia que o desmascarou (desmistificou). Na conjuntura patriarcal do judaísmo, Jesus, personagem principal do cristianismo, legou para os cristãos, inclusive os adeptos da cultura da dominação da mulher pelo homem, um tratamento diferenciado, numa época em que elas não tinham sequer direitos. Com efeito, a própria Bíblia revela a influencia da mulher no ministério de Jesus.

Não obstante, a igreja cristã, desde a igreja primitiva, deturpou a visão da mulher, e a têm oprimido. Diante desta atitude da igreja perante a mulher, pode-se pontuar que há uma discordância em relação aos ensinamentos de Cristo, descritos na Bíblia.

Desta forma, a moral cristã por ter se posicionado de forma rígida sobre o papel da mulher na sociedade, tem sido questionada pela própria Bíblia, a qual comprova o caráter de equidade com que Jesus tratou as mulheres. Parodiando Marx, o sistema trouxe dentro de si os germes de sua própria destruição.

Sendo assim, a cultura judaico-cristã que tem deixado adeptos que persistem em perpetuar a violência simbólica contra a mulher, está cada vez mais sendo questionada pela academia, através de estudos de gênero, e neste artigo, pelos próprios escritos do criador do cristianismo, que colocou a mulher em condição e tratamento de 
igualdade, sem desvalorização, e principalmente preconceitos. Outrossim, é preciso um olhar mais atento da academia para as sutilezas dos livros considerados sagrados, pois podem trazer importantes elementos para se compreender os muitos mitos e tabus das relações de gênero presentes na contemporaneidade.

\section{JEWISH-CREST IDEOLOGY: A SYMBOLIC VIOLENCE AGAINST WOMEN HISTORICALLY TRANSMITTED AND REPRODUCED BY SCHOOL STAFF}

ABSTRACT: The ideology of religious thought coming transits in society through their formers. In the school context we note an applicable reality violence to the concept of establishing a culture of submission of women to man and that reproduces by these agents. In fact the religious ideology of Judeo - Christian culture came to education in its various nuances, including school culture subtly through the internalization of its concepts by individuals who have assimilated as natural. Considering this fact, the present study, a theoretical nature, discusses the concept of ideology, seeking to understand the trajectory of the subjection of women from antiquity to the present day and outlines the policy framework of counter-ideology. In general, seeks to show that the supporters of the Judeo - Christian culture persist in perpetuating symbolic violence against women which has been increasingly questioned, especially when confronted with the writings of the founder of Christianity, which put the woman in condition and equal treatment without impairment. Furthermore, this article denounces it takes a closer look at the academy to the subtleties of books considered sacred because they can provide important information for understanding the many myths and taboos of gender relations in contemporary gifts

KEYWORDS: Symbolic Violence. Woman. Ideology. School. Gender relations.

\section{REFERÊNCIAS}

ABREU FILHO, O. Dona Beija: análises de um mito. In: FRANCHETTO, B. (Org.). Perspectivas antropológicas da mulher. Rio de Janeiro: Zahar, 1981. p.73-108.

ADAMSON, M. Jesus e o feminismo. Disponível em:

<http://www.suaescolha.com/wires/women.html>. Acesso em: 23 mai. 2006.

ALTHUSSER, L. Aparelhos ideológicos de Estado. 2.ed. Trad. de Valter José Evangelista e Maria Laura Viveiros de Castro. Rio de Janeiro: Graal, 1985.

ARAÚJO, M. C. Uma releitura do patriarcalismo hebreu da Bíblia, em diálogo com o feminismo cristão na contemporaneidade. História Agora, São Paulo, v.1, p.283-304, 2012.

BADALONI, N. Sobre a teoria Gramsciana de ideologia. Rio de Janeiro: Civilização Brasileira, 1978. 
BÍBLIA. Português. Bíblia sagrada. Ed. rev. atual. Tradução de João Ferreira Almeida. Barueri: Sociedade Bíblica do Brasil, 1978.

BOURDIEU, P. Meditações Pascalianas. Rio de Janeiro: Bertrand Brasil, 2001.

BOURDIEU, P.; PASSERON, J. C. A reprodução: elementos para uma teoria do sistema de ensino. Rio de Janeiro: Francisco Alves, 1975.

BROWN, P. Corpo e sociedade, o homem, a mulher e a renúncia sexual do início do cristianismo. Rio de Janeiro: Jorge Zahar, 1990.

CHAUÍ, M. O que é ideologia. 5.ed. São Paulo: Brasiliense, 1980.

GRAMSCI, A. A concepção dialética da historia, 10.ed. Rio de Janeiro: Civilização Brasileira, 1995.

Os intelectuais e a organização da cultura. 10.ed. Rio de Janeiro: Civilização Brasileira, 1978.

JOLL, J. As ideias de Gramsci. Tradução de James Amado. São Paulo: Cultrix, 1977.

KING, K. L. Women in ancient christianity: the new discoveries. Frontline, Boston, abr. 1998. Disponível em:

<http://www.pbs.org/wgbh/pages/frontline/shows/religion/first/women.html>. Acesso em: 11 set. 2015.

LIMA NETO, F. P.; LEÃO, A. M.C. Violência simbólica contra educandos transmitida historicamente pela cultura dominante. Trama interdisciplinar, São Paulo, v.4, n.2, p.151-162, 2013.

MACEDO, J. R. A mulher na idade média. São Paulo: Contexto, 1990.

MARX, K.; ENGELS, F. A ideologia alemã. 2.ed. São Paulo: Ed. Ciências Humanas, 1979.

NUNES, C. Desvendando a sexualidade. Campinas: Papirus, 1987.

PETERSEN, Á. T. Discutindo o uso da categoria gênero e as teorias que respaldam estudos de gêneros. In: ROSO, A. et al. (Org.). Gênero por escrito: saúde, identidade e trabalho. Porto Alegre: Ed. da PUC, 1999. p.15-39.

SILVA, F. R. Maria Madalena e as mulheres no cristianismo primitivo. 2008. $116 \mathrm{f}$. Dissertação (Mestrado em Ciências da Religião) - Faculdade de Filosofia e Ciências da Religião, Universidade Metodista, São Bernardo do Campo, 2008. 